\title{
Factors associated with breakfasting in users of a public health service
}

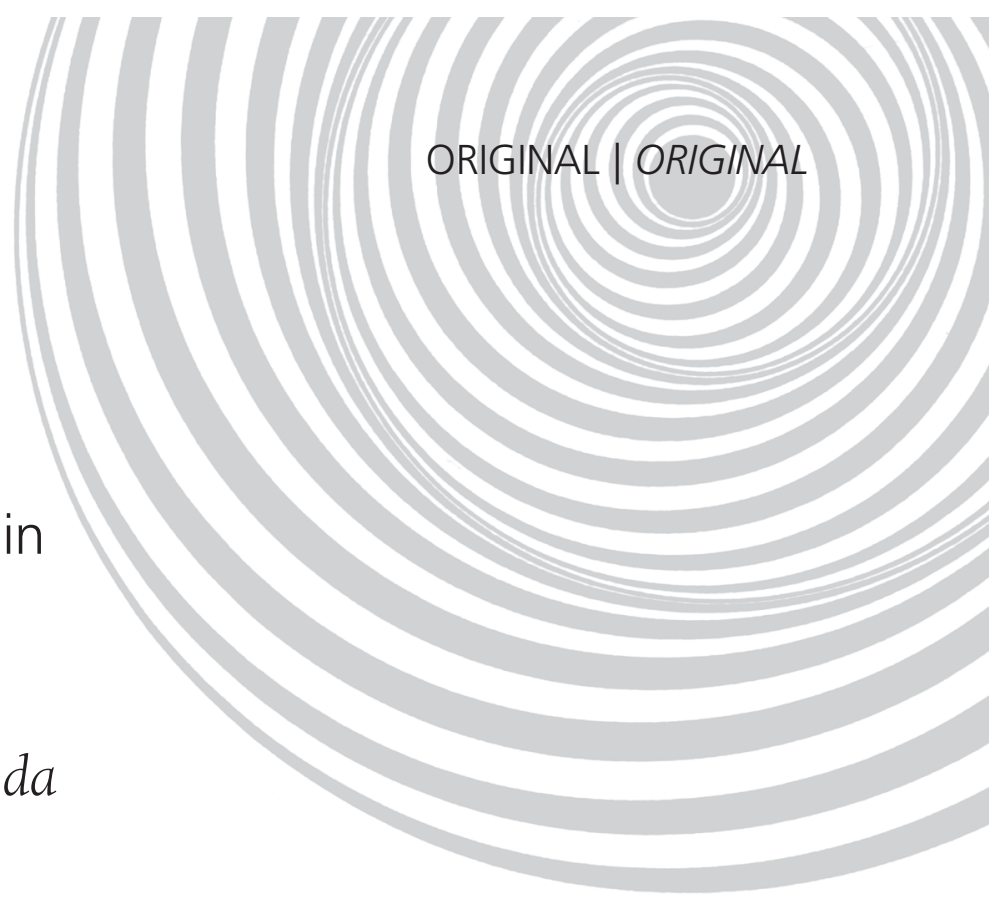

\author{
Fatores associados à realização do café da \\ manhã em serviço público de saúde
}

Patrícia Pinheiro de FREITAS ${ }^{1}$

Raquel de Deus MENDONÇA ${ }^{1}$

Aline Cristine Souza LOPES ${ }^{2}$

A B S T R A C T

\section{Objective}

This study identified the sociodemographic, lifestyle, dietary and anthropometric factors of users of a public health promotion service who have breakfast regularly.

\section{Methods}

This cross-sectional study included all users aged 20 years or more who joined the service between March 2007 and December 2010. Their socioeconomic and anthropometric data, dietary habits and health status were investigated. Statistical treatment included the Chi-square, Mann-Whitney, Fisher's exact and Student's $t$ tests and Poisson regression analysis $(p<0.05)$.

\section{Results}

Most of the participants $(87.1 \%, n=528)$ breakfasted often, especially those aged 48.5 years or more $(p=0.041)$. Poisson regression analysis showed association between breakfasting often and not smoking (PR=1.45, 95\% Cl: 1.10-1.91), having a greater number of daily meals $(P R=1.15,95 \% \mathrm{Cl}: 1.06-1.25)$, appropriate intake of deepfried foods ( $P R=1.12,95 \% \mathrm{Cl}: 1.01-1.25)$, lower fat intake ( $P R=0.78,95 \% \mathrm{Cl}: 0.68-0.89)$ and smaller prevalence of excess weight ( $\mathrm{PR}=0.85,95 \% \mathrm{Cl}: 0.78-0.92)$.

\section{Conclusion}

The positive relationship found between breakfasting often and not smoking, appropriate food and nutrient intakes and a healthier body weight shows the need of emphasizing this meal in health services as a simple and doable health promotion strategy that helps to prevent and control chronic diseases.

Indexing terms: Health promotion. Lifestyle. Nutrition. Obesity. Public health.

\footnotetext{
${ }^{1}$ Nutricionistas, Universidade Federal de Minas Gerais, Escola de Enfermagem, Grupo de Pesquisa de Intervenções em Nutrição. Belo Horizonte, MG, Brasil.

${ }^{2}$ Universidade Federal de Minas Gerais, Escola de Enfermagem, Programa de Pós-Graduação em Enfermagem. Av. Alfredo Balena, 190, Sala 420, Santa Efigênia, 30130-100, Belo Horizonte, MG, Brasil. Correspondence to/Correspondência para: ACS LOPES. E-mail: <aline@enf.ufmg.br>.

Apoio: Fundação de Amparo à Pesquisa do Estado de Minas Gerais, Registro CDS APQ 0376- 408/07.
} 
196 | PP FREITAS et al.

\section{RE S U M O}

\section{Objetivo}

Identificar os fatores sociodemográficos, de estilo de vida, dietéticos e antropométricos relacionados à realização do café da manhã entre os ingressos de serviço público de Promoção à Saúde.

\section{Métodos}

Estudo transversal com todos os usuários, com 20 anos ou mais, que ingressaram no serviço no período de março de 2007 a dezembro de 2010. Investigaram-se dados socioeconômicos, hábitos alimentares, perfil antropométrico e de saúde. Realizaram-se os testes Qui-quadrado, Mann Whitney, Exato de Fisher e $t$ de Student, e análise de regressão de Poisson $(p<0,05)$.

\section{Resultados}

Dos participantes $(n=528), 87,1 \%$ realizavam frequentemente o café da manhã, sendo mais prevalente entre aqueles com 48,5 anos ou mais $(p=0,041)$. A análise de regressão de Poisson revelou associação entre a realização frequente do café da manhã com o hábito de não fumar ( $R P=1,45$; IC95\%:1, 10-1,91); maior número de refeições diárias ( $R P=1,15$; IC95\%:1,06-1,25); consumo adequado de frituras ( $R P=1,12$; IC95\%:1,01-1,25); menor ingestão de lipídios na dieta $(R P=0,78$; IC95\%:0,68-0,89) e menor prevalência de excesso de peso (RP=0,85; IC95\%:0,78-0,92).

\section{Conclusão}

A relação positiva encontrada entre o consumo do café da manhã com o não tabagismo, ingestão adequada de alimentos e nutrientes, e um peso mais saudável, denota a necessidade de se enfatizar esta refeição, enquanto estratégia simples e factível de aconselhamento de promoção da saúde, de forma a contribuir para a prevenção e o controle de doenças crônicas em serviços de saúde.

Termos de indexação: Promoção da saúde. Estilo de vida. Nutrição. Obesidade. Saúde pública.

\section{INTRODUCTION}

Breakfast, defined as the first meal of the day, should respond for $25 \%$ of the daily energy intake 1 . However, recent lifestyle changes, lack of time and eating away from home have promoted new eating behaviors that contribute to skipping breakfast ${ }^{2}$.

Skipping breakfast has been observed in different life cycles and 14 to $30 \%$ of all adults do it ${ }^{3}$. Although the frequency of breakfasting increases with age, it is the most neglected meal among adults when compared with lunch and supper ${ }^{3,4}$. Its nutritional composition has also been affected, being limited to pure coffee or milk and coffee, and bread. Brazilians still habitually consume butter or margarine but the consumption of fruits is rare ${ }^{5}$. Alves $\&$ Boog $^{4}$ found that $30 \%$ of their sample did not breakfast and only $13 \%$ had a complete breakfast, that is, one with body-regulating foods such as fruits and calcium sources.
Many factors have been associated with skipping breakfast, such as smoking, consumption of alcoholic beverages, physical inactivity, low education level and being male ${ }^{6}$. Moreover, there is lack of time and hunger, and the desire to diet and lose weight. Skipping breakfast to eat small snacks later may lead to a higher intake of carbohydrates and fats, and consequently, of calories ${ }^{7}$.

Individuals who breakfast present a higher intake of healthier foods, such as milk, fruits, vegetables and grains, instead of foods high in calories, fats and sugar ${ }^{8}$. Hence, breakfast has been associated with positive health effects ${ }^{6,9}$, such as increased satiety, smaller daily energy intake, better glycemic control ${ }^{10}$, lower risk of gaining weight ${ }^{3,6,7}$ and visceral fat ${ }^{9}$, and lower risk of weight-related comorbidities, such as hypertension, diabetes Mellitus and cardiovascular diseases ${ }^{7,10}$.

Despite the importance of breakfast to health, there is little information in the Brazilian 
literature about this meal, and it is not offered in health services. Nevertheless, according to the country's public policies, primary healthcare is the main location for the development of healthpromoting and disease-preventing and - controlling actions $^{11}$. In this sense, the objective of this study was to identify the sociodemographic, lifestyle, dietary and anthropometric factors of users of a public health-promotion service according to breakfasting frequency.

\section{METHODS}

A cross-sectional study was done from March 2007 to December 2010 with all users aged 20 years or more of a health-promotion service of Belo Horizonte, Minas Gerais, called Academia da Cidade (city gym). The city gyms provided regular physical activity and nutritional advice to individuals aged 18 years or more living in city areas of high social vulnerability ${ }^{12}$.

The data were collected by a pretested questionnaire ${ }^{13}$. The questionnaire was adapted to the reality of the city gyms. Some questions were changed and some were added, such as questions that investigate the use of medications. The questionnaire was administered by dieticians and trained trainee dieticians and collected sociodemographic data (gender, age, job, number of individuals in household, household income per capita and education (evel); dietary habits (mastication quality, snacking between meals, drinking while eating main meals, intake of chicken skin and visible fat in meat, per capita intake of salt, vegetable oil and sugar), health profile (reported diseases, perceived body image, use of medications and smoking status), food intake data and anthropometric data ${ }^{13}$.

Food intake was investigated by a 24 hour recall (R24) associated with a qualitative Food Frequency Questionnaire (FFQ) with a list of 30 foods covering the last six months ${ }^{13}$. This study selected eleven foods for analysis according to the plausibility reported in the literature ${ }^{4,5,8}$. The consumption of some foods was $100 \%$ adequate, so they were excluded from the analysis.
Fruit and vegetable intake adequacies were determined by the World Health Organization $(\mathrm{WHO})^{14}$. The intake adequacies of salt, sugar, oil, water, milk and dairy products, sandwich cookies, sweets, deep-fried foods, sodas and powdered drink mixes were determined by the Food Guide for the Brazilian Population (Guia Alimentar para a População Brasileira) ${ }^{15}$.

The data collected by the R24 was analyzed by the software Diet Win ${ }^{\circledR}$ Professional version 2.0. Measurements in cooking units were converted to grams using a specific table. Food composition was analyzed by different food composition tables, preparation recipes and food labels, when necessary ${ }^{13}$.

The study nutrients were calories, carbohydrates, proteins, fats, saturated fatty acids, monounsaturated fatty acids, polyunsaturated fatty acids, cholesterol, calcium, iron, zinc, sodium, fibers and vitamins $A, D, E, C$ and $B_{12}$. Energy and macronutrient intakes were classified as recommended by the Institute of Medicine $(\mathrm{IOM})^{16}$ according to gender and age. Micronutrient intakes were classified as inadequate, adequate or excessive according to the IOM recommendations ${ }^{17}$ and fatty acid and cholesterol intakes were classified according to the WHO's recommendations ${ }^{14}$.

Weight, height, Waist Circumference (WC) and Hip Circumference $(\mathrm{HC})$ were collected as recommended by the $\mathrm{WHO}^{18}$ for determining nutritional status.

Body mass index was calculated by dividing the weight $(\mathrm{kg})$ by the square of the height $\left(\mathrm{m}^{2}\right)$ and classified according to age. For adults, the cut-off points proposed by the $\mathrm{WHO}^{18}$ were used and for the elderly, those proposed by the Nutrition Screening Initiative ${ }^{19}$ were used. For presentation of the data, adults and elderly were classified as underweight, normal weight and excess weight. WC and Waist-to-Hip Ratio (WHR) were classified as recommended by the $\mathrm{WHO}^{20}$.

Breakfasting, the dependent variable of this study, was assessed by asking the participants how many times a week they breakfasted. For 
data analysis, the variable was dichotomized into frequent breakfasting (4 times or more per week) and occasional breakfasting (less than 4 times per week). The reference category was frequent breakfasting.

Statistical analyses included the Chisquare, Mann-Whitney, Fisher's exact and Student's $t$ tests. The variables with normal distribution according to the statistical Kolmogorov-Smirnov test were presented as mean and standard deviation and the remainder variables as median, minimums and maximums.

For Poisson regression analysis with robust variance, the response variable was considered frequent breakfasting. The variables with significance smaller than 0.20 or those considered relevant in the study context were tested with the response variable. The dichotomized variables were categorized as 0 and 1 and the other categorical variables were transformed into dummy variables. The variables were adjusted to the model by the backward stepwise method. The
Prevalence Ratio (PR) with a Confidence Interval of $95 \%(95 \% \mathrm{Cl})$ was used as effect measure. The significance level for all tests was set at $5 \%$ $(p<0.05)$. The data were treated by the software Stata version 7.0.

This study was approved by the Research Ethics Committees of the Universidade Federal de Minas Gerais, under protocol number ETIC 103/2007, and of Belo Horizonte City Hall, under protocol number 087/2007. All participants signed a free and informed consent form after being informed about the study.

RES U L T S

A total of 528 users participated in the study. Most were women with a mean age of $48.0 \pm 13.0$ and low per capita income. The prevalence of reported morbidities was high, especially high blood pressure and high cholesterol level (Table 1).

Table 1. Sociodemographic and health characteristics of the users of a health-promotion service of Belo Horizonte, according to breakfasting frequency. Belo Horizonte (MG), Brazil, 2010.

\begin{tabular}{|c|c|c|c|c|}
\hline \multirow{2}{*}{ Variables } & \multicolumn{3}{|c|}{ Breakfasting frequency } & \multirow{2}{*}{$p$ value } \\
\hline & Total $(n=528)$ & Frequent $(n=460)$ & Occasional $(n=68)$ & \\
\hline Age (years) & $48.0 \pm 13.0$ & $48.5 \pm 12.8$ & $45.0 \pm 14.4$ & $0.041^{\mathrm{a}}$ \\
\hline Females (\%) & 90.7 & 86.9 & 91.3 & $0.229^{b}$ \\
\hline Monthly per capita income ( $R \$)$ & $333.33(22.0 ; 2700.00)$ & $333.33(22.0 ; 2700.00)$ & $340.00(28.00 ; 2250.00)$ & $0.368^{c}$ \\
\hline Number of people in household & $4.0(1.0 ; 15.0)$ & $4.0(1.0 ; 15.0)$ & $3.5(1.0 ; 6.0)$ & $0.650^{c}$ \\
\hline \multicolumn{5}{|l|}{ Education level } \\
\hline 4 years or less & 29.0 & 28.7 & 30.9 & \multirow[t]{2}{*}{$0.711^{\mathrm{b}}$} \\
\hline 5 years or more & 71.0 & 71.3 & 69.1 & \\
\hline \multicolumn{5}{|l|}{ Occupation (\%) } \\
\hline Unemployed & 7.2 & 4.4 & 7.4 & \multirow{4}{*}{$0.695^{b}$} \\
\hline Retired & 14.9 & 14.7 & 14.9 & \\
\hline Homemaker & 28.8 & 26.5 & 29.1 & \\
\hline Other & 49.1 & 54.4 & 48.4 & \\
\hline \multicolumn{5}{|l|}{ Reported diseases (\%) } \\
\hline High blood pressure & 48.9 & 40.7 & 43.3 & $0.693^{b}$ \\
\hline High cholesterol & 28.7 & 28,7 & 30.0 & $0.831^{b}$ \\
\hline High triglycerides & 13.6 & 14.0 & 10.2 & $0.416^{b}$ \\
\hline Diabetes Mellitus & 8.9 & 6.3 & 9.3 & $0.421^{b}$ \\
\hline Use of medications (\%) & 67.4 & 67.8 & 64.7 & $0.617^{b}$ \\
\hline Smoker (\%) & 11.0 & 8.1 & 28.3 & $<0.001^{b}$ \\
\hline Healthy body image (\%) & 31.4 & 14.9 & 29.3 & $0,006^{\mathbf{b}}$ \\
\hline
\end{tabular}

Note: aStudent's $t$ test; ${ }^{\mathbf{b}}$ Chi-square test; 'Mann Whitney test. 
Table 2. Dietary habits of users of a health-promotion service of Belo Horizonte, according to breakfasting frequency. Belo Horizonte (MG), Brazil, 2010

\begin{tabular}{lcccc}
\hline \multirow{2}{*}{ Variables (\%) } & \multicolumn{3}{c}{ Breakfasting frequency } & p value \\
\cline { 2 - 3 } & Total $(\mathrm{n}=528)$ & Frequent $(\mathrm{n}=460)$ & Occasional $(\mathrm{n}=68)$ & $0.037^{\mathrm{a}}$ \\
\hline Chews food well & 72.8 & 61.1 & 47.8 & $0.126^{\mathrm{a}}$ \\
Consumes beverages during main meals & 54.0 & 52.7 & 62.7 & $<0.001^{\mathrm{b}}$ \\
Number of meals per day & $4.0(0.0 ; 8.0)$ & $4.0(2.0 ; 8.0)$ & $3.0(0.0 ; 7.0)$ & $0.287^{\mathrm{a}}$ \\
Snacks between meals & 50.8 & 51.9 & 43.5 & $0.088^{\mathrm{a}}$ \\
Eats chicken skin & 65.5 & 66.8 & 55.7 & $0.071^{\mathrm{a}}$ \\
Eats apparent meat fat & 28.2 & 29.9 & 17.6 & $0.315^{\mathrm{a}}$ \\
Appropriate intake & & & & $0.525^{\mathrm{a}}$ \\
Salt & 58.0 & 57.1 & 63.9 & $0.187^{\mathrm{a}}$ \\
Sugar & 24.6 & 25.1 & 21.3 & $0.969^{\mathrm{a}}$ \\
Oil & 10.9 & 11.6 & 31.3 & $0.015^{\mathrm{a}}$ \\
Fruits and vegetables & 31.0 & 31.0 & 38.8 & $0.210^{\mathrm{a}}$ \\
Water & 26.6 & 24.7 & 4.4 & $0.027^{\mathrm{a}}$ \\
Milk and dairy products & 8.4 & 8.9 & 89.6 & $0.094^{\mathrm{a}}$ \\
Sandwich cookies & 95.0 & 95.8 & 61.8 & $<0.001^{\mathrm{a}}$ \\
Sweets & 70.4 & 71.7 & 45.6 & $0.258^{\mathrm{a}}$ \\
Deep-fried foods & 65.5 & 68.4 & 75.0 & $0.286^{\mathrm{a}}$ \\
Soda & 80.1 & 80.9 & 45.6 & $0.018^{\mathrm{a}}$ \\
Powdered drink mixes & 51.6 & 52.5 & 29.4 & \\
Weekly intake of alcoholic beverages & 18.9 & 17.4 & & \\
\hline
\end{tabular}

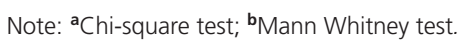

Table 3. Nutrient and calorie intake of the users of a health-promotion service of Belo Horizonte, according to breakfasting frequency. Belo Horizonte (MG), Brazil, 2010.

\begin{tabular}{lcccc}
\hline \multirow{2}{*}{ Variables } & \multirow{2}{*}{ Total $(\mathrm{n}=528)$} & \multicolumn{2}{c}{ Breakfasting frequency } & \multirow{2}{*}{$p$ value } \\
\cline { 3 - 4 } & & Frequent $(\mathrm{n}=460)$ & Occasional $(\mathrm{n}=68)$ & \\
\hline Calories (kcal) & $1671.0(324.0 ; 6.254 .0)$ & $1676.0(324.0 ; 5432.0)$ & $1578.0(519.0 ; 6254.0)$ & $0.227^{\mathrm{a}}$ \\
Carbohydrates (\%) & $49.8 \pm 10.4$ & $50.3 \pm 10.0$ & $46.4 \pm 12.6$ & $0.004^{\mathrm{b}}$ \\
Proteins (\%) & $14.0(2.7 ; 68.5)$ & $13.8(2.7 ; 68.5)$ & $14.2(4.7 ; 32.8)$ & $0.633^{\mathrm{a}}$ \\
Lipids (\%) & $33.9 \pm 9.7$ & $34.5 \pm 9.7$ & $37.2 \pm 9.9$ & $0.033^{\mathrm{b}}$ \\
Saturated fatty acids (\%) & $9.5(1.0 ; 43.2)$ & $9.4(1.0 ; 43.2)$ & $9.7(1.7 ; 28.7)$ & $0.821^{\mathrm{a}}$ \\
Monounsaturated fatty acids (\%) & $9.0(0.3 ; 40.4)$ & $8.9(0.3 ; 24.7)$ & $9.8(1.9 ; 40.4)$ & $0.049^{\mathrm{a}}$ \\
Polyunsaturated fatty acids (\%) & $10.5(1.8 ; 31.9)$ & $10.5(1.8 ; 31.9)$ & $10.0(3.0 ; 24.2)$ & $0.370^{\mathrm{a}}$ \\
Cholesterol (mg) & $164.2(0.0 ; 1383.3)$ & $160.3(0.0 ; 1097.4)$ & $179.2(0.0 ; 1383.3)$ & $0.274^{\mathrm{a}}$ \\
Calcium (mg) & $344.0(0.0 ; 3506.6)$ & $335.2(0.0 ; 3506.6)$ & $261.7(11.2 ; 1195.6)$ & $0.001^{\mathrm{a}}$ \\
Sodium (g) & $3.4(0.2 ; 47.6)$ & $3.5(0.5 ; 34.6)$ & $3.2(0.2 ; 9.9)$ & $0.241^{\mathrm{a}}$ \\
Vitamin D (mcg) & $1.5(0.0 ; 388.6)$ & $1.5(0.0 ; 388.6)$ & $0.8(1.0 ; 42.2)$ & $0.036^{\mathrm{a}}$ \\
Iron (mg) & $6.7(0.6 ; 84.7)$ & $6.7(0.6 ; 84.7)$ & $6.9(1.1 ; 37.8)$ & $0.667^{\mathrm{a}}$ \\
Zinc (m) & $6.5(0.3 ; 73.6)$ & $6.6(0.3 ; 73.6)$ & $6.4(1.6 ; 35.2)$ & $0.704^{\mathrm{a}}$ \\
Vitamin A (mcg) & $466.2(0.0 ; 29276.7)$ & $479.1(0.0 ; 23053.7)$ & $409.4(1.3 ; 29276.7)$ & $0.506^{\mathrm{a}}$ \\
Vitamin E (mg) & $27.9(0.0 ; 108.1)$ & $27.9(0.0 ; 108.1)$ & $28.7(3.6 ; 84.2)$ & $0.947^{\mathrm{a}}$ \\
Vitamin C (mg) & $48.2(0.2 ; 3600.5)$ & $49.3(0.2 ; 3600.5)$ & $36.8(0.3 ; 1204.4)$ & $0.261^{\mathrm{a}}$ \\
Vitamin B 12 (mcg) & $1.3(0.0 ; 216.0)$ & $1.4(0.0 ; 169.0)$ & $1.3(0.0 ; 216.0)$ & $0.498^{\mathrm{a}}$ \\
Fibers (g) & $16.8(0.4 ; 68.7)$ & $17.4(0,5 ; 68.7)$ & $15.0(0.4 ; 53.0)$ & $0.097^{\mathrm{a}}$ \\
\hline
\end{tabular}

Note: aMann Whitney test; 'bstudent's $t$ test. 
Most of the users (87.1\%) breakfasted frequently, the median being $7.0(0.0 ; 7.0)$ days a week.

Individuals who breakfasted frequently were older ( $p=0.041)$, often nonsmokers $(p<0.001)$, and had better perceived body image $(p=0.006)$ (Table 1). Additionally, they had more meals per day $(p<0.001)$, reported chewing foods well $(p=0.037)$, and consumed less deep-fried foods $(p<0.001)$, sandwich cookies $(p=0.027)$ and alcoholic beverages - less than once a week $(p=0.018)$. On the other hand, their water intake was inadequate $(p=0.015)$ (Table 2).

The nutrients related to breakfasting frequently were carbohydrates $(p=0.004)$, fats $(p=0.033)$, calcium $(p=0.001)$ and vitamin $D$ $(p=0.036)$ (Table 3$)$. Adequate nutrient intake was associated with inadequate carbohydrate intake $(p=0.017)$ and adequate vitamin $B_{12}$ intake $(p<0.001)$ (Data not shown).

Analysis of anthropometric characteristics showed that those who breakfasted frequently had lower median weight ( $p=0.007)$, and lower risk of developing metabolic disorders according to WC ( $p=0.020)$ (Table 4).
Once the model was adjusted by Poisson's multivariate analysis, associations were found between breakfasting frequently (four or more times per week) and not smoking, having five or more meals a day, appropriate consumption of deep-fried foods, lower fat intake and lower prevalence of excess weight (Table 5).

\section{DISCUSSION}

The prevalence of breakfasting frequently was high and positively associated with appropriate food and nutrient intakes, which have a positive repercussion on the body weight. It is noteworthy that this study was done in a public health service, which shows the importance of knowing the dietary profile and associated factors of its users to improve the number of healthpromotion actions.

The prevalence of breakfasting was similar to those found by other studies, which varied from $25.2 \%$ to $95.0 \%{ }^{4,6-9,21,22}$. Although skipping breakfast was unusual, it may lead to nutritional deficiencies and increase the intake of energydense foods, favoring the development of diseases $8,10,23$.

Table 4. Nutritional status of users of a health-promotion service of Belo Horizonte, according to breakfasting frequency. Belo Horizonte (MG), 2010.

\begin{tabular}{|c|c|c|c|c|}
\hline \multirow{2}{*}{ Variables } & \multirow{2}{*}{ Total $(n=528)$} & \multicolumn{2}{|c|}{ Breakfasting frequency } & \multirow{2}{*}{$p$ value } \\
\hline & & Frequent $(n=460)$ & Occasional $(n=68)$ & \\
\hline Weight (kg) & $69.5(39.1 ; 146.8)$ & $68.8(39.1 ; 146.8)$ & $73.8(46.0 ; 118.5)$ & $0.007^{\mathrm{a}}$ \\
\hline BMI $\left(\mathrm{kg} / \mathrm{m}^{2}\right)$ & $28.0(14.9 ; 62.1)$ & $27.9(14.9 ; 62.1)$ & $28.7(18.9 ; 52.0)$ & $0.168^{a}$ \\
\hline \multicolumn{5}{|l|}{ Nutritional status (\%) } \\
\hline Underweight & 1.9 & 2.2 & 0.0 & \multirow{3}{*}{$0.181^{b}$} \\
\hline Normal weight & 27.8 & 28.7 & 21.2 & \\
\hline Excess weight & 70.3 & 69.0 & 78.8 & \\
\hline Waist circumference $(\mathrm{cm})$ & $86.8 \pm 12.0$ & $86.4 \pm 12.5$ & $89.6 \pm 12.5$ & $0.046^{c}$ \\
\hline No risk & 32.6 & 33.3 & 27.3 & \multirow{3}{*}{$0.020^{d}$} \\
\hline High risk & 27.2 & 28.4 & 18.2 & \\
\hline Very high risk & 40.2 & 38.3 & 54.5 & \\
\hline Waist-to-hip ratio & $0.83(0.65 ; 1.74)$ & $0.83(0.65 ; 1.48)$ & $0.84(0.69 ; 1.74)$ & $0.376^{\mathrm{a}}$ \\
\hline No risk & 54.7 & 55.4 & 50.0 & \multirow{2}{*}{$0.415^{d}$} \\
\hline Very high risk & 45.3 & 44.6 & 50.0 & \\
\hline
\end{tabular}

Note: a Mann Whitney test; ${ }^{\mathbf{b}}$ Fisher's exact test; ' ${ }^{\text {SStudent's } t}$ test; ${ }^{\mathbf{d}}$ Chi-square test. BMI: Body Mass Index. 
Table 5. Poisson regression analysis for frequent breakfasting according to the characteristics of users of a health-promotion service of Belo Horizonte (MG), 2010

\begin{tabular}{lcc}
\hline Variables & Frequent breakfasting - RP (IC 95\%) & $p$ value a $^{\text {a }}$ \\
\hline Smoker & 1.0 & \\
Yes & $1.45(1.10 ; 1.91)$ & \\
No & 1.0 & \\
Number of daily meals & $1.15(1.06 ; 1.25)$ & $<0.001$ \\
$<5$ meals & & \\
$\geq 5$ meals & 1.0 & 0.034 \\
Intake of deep-fried foods & $1.12(1.01 ; 1.25)$ & \\
Inappropriate & & 0.002 \\
Appropriate & 1.0 & $<0.001$ \\
Fat intake & $0.82(0.73 ; 0.93)$ & \\
Low & $0.78(0.68 ; 0.89)$ & \\
Appropriate & & 0.057 \\
High & 1.0 & $<.001$ \\
Nutritional status & $0.89(0.80 ; 1.00)$ & \\
Underweight & $0.85(0.78 ; 0.92)$ & \\
Normal weight & & \\
Excess weight & & \\
\hline
\end{tabular}

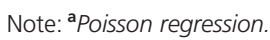

Adjusted by age. Model adjustment: Goodness of fit=1.00.

There are only a few studies that approach the factors associated with skipping breakfast. In general, they report a positive association between breakfasting and healthy lifestyles, such as not smoking, being physically active, controlling body weight and avoiding alcoholic beverages $5^{3,6,7,10,24}$.

In agreement with other studies $6,7,10$, the present study found an association between not smoking and breakfasting frequently. Smoking may reduce appetite in the morning and encourage the smoker to skip this meal ${ }^{7}$.

Individuals who reported breakfasting frequently had more meals per day and appropriate intakes of deep-fried foods and fats. Making smaller meals, including breakfast, is mentioned in the literature as a way to avoid eating too much, which helps to control weight and avoid excess weight-associated comorbidities $^{9,10,25}$.

The greater intake adequacy of deep-fried foods and fats by those who breakfast frequently may indicate a healthier diet, that is, lower consumption of deep-fried foods and high-fat foods. Additionally, the literature has evidenced the replacement of this meal by unhealthy, high-fat snacks, such as processed cookies and chips ${ }^{8,21}$. Thus, breakfasting may contribute to appropriate nutrient intake, consequently promoting health and preventing disease, and accordingly, it is related to healthier behaviors that impact food choices $^{21}$.

A possible consequence of the beneficial health effects of breakfasting is the lower body weight of those who breakfast frequently. This meal has also been associated with less visceral fat and higher percentage of lean mass ${ }^{9,24}$. It is known that reduction of body weight and fat percentage is important for the prevention and control of diseases, especially cardiovascular diseases and glucose intolerance, and, consequently, diabetes Mellitus ${ }^{9,24,26}$. Corroborating these findings, Pereira et al. ${ }^{10}$ observed better blood glucose control in people who breakfasted frequently. 
Knowing the breakfasting frequency and associated factors of users of the Unified Healthcare System (Sistema Único de Saúde - SUS) may allow the development of more effective health actions for the population. Furthermore, such initiatives corroborate Brazilian health policies, such as the National Food and Nutrition Policy (Política Nacional de Promoção da Saúde - PNAM) ${ }^{11}$ and the Health Promotion Policy ${ }^{27}$, which strongly indicate that appropriate health and nutrition are the paths to good health.

The cross-sectional design of this study prevents an assessment of causality among the variables, such as the relationship between breakfasting and lower body weight. However, the type of study done meets the proposed objectives.

Data analysis must consider the occurrence of answer bias, since those who join a healthpromotion service are probably willing to change their food habits, and so may report breakfasting more often. Still, the information analyzed herein was obtained as soon as these individuals joined the service, before any interventions were done, so minimizing the occurrence of biases.

Regarding the use of only one R24, one must consider its advantages when compared with other methods, such as the possibility of using it in health services and the fact that it records the consumption of a high variety of foods, since it is an open instrument. Notwithstanding, the collected information may be affected by the individual's recording skill and a single R24 may not reflect the individual's food habits $^{28}$. Given these limitations, this study associated the R24 with the qualitative FFQ, and a relatively high number of individuals were studied, which improves method quality.

The present study found a positive association between breakfasting frequently and healthy life habits. This finding suggests that promoting breakfasting may contribute to the prevention and control of non-communicable chronic diseases and disorders, and to improving health and quality of life, given its relationship with smaller smoking prevalence, appropriate nutrient and food intakes and smaller body weight. The results found by the present study may help professionals working in primary healthcare and health service managers to develop and implement actions that promote breakfasting as a simple and easy strategy for health promotion, and may encourage researchers to perform more studies on the theme.

\section{ACKNOWLEDGMENTS}

We thank the Conselho Nacional de Desenvolvimento Científico e Tecnológico for the scholarship, the Coordenação de Aperfeiçoamento Pessoal de Nivel Superior for the master's scholarship and the Fundação de Amparo à Pesquisa do Estado de Minas Gerais for the grant. We also thank the physical educator Danielle Ibrain for allowing the study to be done at the city gym.

\section{ONTRIBUTORS}

PP FREITAS contributed substantially to study conception and planning, data analysis and interpretation, and manuscript writing. RD MENDONÇA contributed to data analysis and interpretation and critically reviewed the manuscript. ACS LOPES Contributed to study conception and planning, data interpretation and critical review of the manuscript.

\section{REFERÊ NCIAS}

1. Philippi ST. Pirâmide dos alimentos: fundamentos básicos da nutrição. Barueri: Manole; 2008.

2. Rampersaud GC. Benefits of breakfast for children and adolescents: Update and recommendations for practitioners. Am J Lifestyle Medicine. 2009; 3(2):86-103. doi: 10.1177/1559827608327219.

3. Trancoso SC, Cavalli SB, Proença RPC. Café da manhã: caracterização, consumo e importância para a saúde. Rev Nutr. 2010; 23(5):859-69. doi: 10.1590/S1415-52732010000500016.

4. Alves HJ, Boog MCF. Comportamento alimentar em moradia estudantil: um espaço para promoção 
da saúde. Rev Saúde Pública. 2007; 41(2):197-204. doi: 10.1590/S0034-89102007000200005.

5. Mattos LL, Martins IS. Consumo de fibras alimentares em população adulta. Rev Saúde Pública. 2000; 34(1):50-5. doi: 10.1590/\$0034-89102000 000100010.

6. Keski-Rahkonen A, Kaprio J, Rissanen A, Virkkunen $M$, Rose RJ. Breakfast skipping and health compromising behaviors in adolescents and adults. Eur J Clin Nutr. 2003; 57(7):842-53. doi: 10.1038/ sj.ejcn. 1601618.

7. Song W, Chun O, Obayashi S, Cho S. Chung C. Is consumption of breakfast associated with body mass index in US adults? J Am Diet Assoc. 2005; 105(9):1373-82. doi: 10.1016/j.jada.2005.06.002.

8. Haire-Joshu D, Schwarz C, Budd E, Yount BW, Lapka C. Postpartum teens' breakfast consumption is associated with snack and beverage intake and body mass index. J Am Diet Assoc. 2011; 111(1): 124-30. doi: 10.1016/j.jada.2010.10.009.

9. Alexander KE, Ventura EE, Spruijt-Metz D, Weigensberg MJ, Goran MI, Davis JN. Association of breakfast skipping with visceral fat and insulin indices in overweight Latino youth. Obesity. 2009; 17(8):1528-33. doi: 10.1038/oby.2009.127.

10. Pereira MA, Erickson E, McKee P, Schrankler K, Raatz SK, Lytle LA, et al. Breakfast frequency and quality may affect glycemia and appetite in adults and children. J Nutr. 2011; 141(1):163-8. doi: 10.39 45/jn.109.114405.

11. Brasil. Ministério da Saúde. Secretária de Atenção Básica. Política Nacional de Alimentação e Nutrição. Brasília: MS; 2011.

12. Dias MAS, Giatti L, Guimarães VR, Amorim MA, Rodrigues CS, Lansky S, et al. BH - Saúde: projeto promoção de modos de vida saudáveis. Pensar BH/ Política Social. 2006; 1:21-2.

13. Lopes ACS, Ferreira AD, Santos LC. Atendimento nutricional na atenção primária á saúde: proposição de protocolos. Nutr Pauta. 2010; 18(101):40-4.

14. World Health Organization. Diet, nutrition and the prevention of chronic diseases. Genebra: WHO; 2003.

15. Brasil. Ministério da Saúde. Guia alimentar para a população brasileira: promovendo a alimentação saudável. Brasília: MS; 2008.

16. Institute of Medicine. Dietary reference intakes for energy, carbohydrate, fiber, fat, fatty acids, cholesterol, protein, and amino acids (macronutrients). Washington (DC): National Academy Press; 2005.

17. Institute of Medicine. Dietary reference intakes: applications in dietary assessment. Washington (DC): National Academy Press; 2000.
18. World Health Organization. Physical status: The use and Interpretation of Anthropometry. Technical Report Series 854. Geneva: WHO; 1995.

19. Nutrition Screening Initiative. Nutrition interventions manual for professionals caring for older Americans. Washington (DC): Nutrition Screening Initiative; 1992.

20. World Health Organization. Waist Circumference and Waist-Hip Ratio: Report of a WHO Expert Consultation. Geneva: WHO; 2011.

21. Utter J, Scragg R, Mhurchu C, Schaaf D. At-home breakfast consumption among New Zealand children: Associations with body mass index and related nutrition behaviors. J Am Diet Assoc. 2007; 107(4):570-6. doi: 10.1016/j.jada.2007.01.010.

22. Araki EL, Tucunduva SP, Flores MM, Chermont ECP, Leal GVS, Alvarenga MS. Padrão de refeições realizadas por adolescentes que frequentam escolas técnicas de São Paulo. Rev Paul Pediatr. 2011; 29(2):164-170. doi: 10.1590/S0103-05822011000 200006.

23. Sivaramakrishnan M, Kamath V. A typical workingday breakfast among children, adolescents and adults belonging to the middle and upper socioeconomic classes in Mumbai, India: Challenges and implications for dietary change. Public Health Nutr. 2012; 30:1-7. doi: 10.1017/S1368980012002777.

24. Hallström L, Labayen I, Ruiz JR, Patterson E, Vereecken CA, Breidenassel C, et al. Breakfast consumption and CVD risk factors in European adolescents: The HELENA (Healthy Lifestyle in Europe by Nutrition in Adolescence) Study. Public Health Nutr. 2012; 12:1-10. doi: 10.1017/S13 68980012000973.

25. Affenito SG. Breakfast: A missed opportunity. J Am Diet Assoc. 2007; 107(4):565-9. doi: 10.1016/j. jada.2007.01.011.

26. Mekary RA, Giovannucci E, Willett WC, Van Fam RM, Hu FB. Eating patterns and type 2 diabetes risk in men: Breakfast omission, eating frequency, and snacking. Am J Clin Nutr. 2012; 95(5):1182-9. doi: 10.3945/ajen.111.028209.

27. Brasil. Ministério da Saúde. Secretária de Vigilância em Saúde. Política Nacional de Promoção da Saúde. Brasília: MS; 2010.

28. Menezes MC, Horta PM, Santos LC, Lopes ACS. Avaliação do consumo alimentar e de nutrientes no contexto da atenção primária à saúde. Ceres. 2011; 6(3):175-90. 
